\title{
International
}

Onganization

me XVII - Number 4

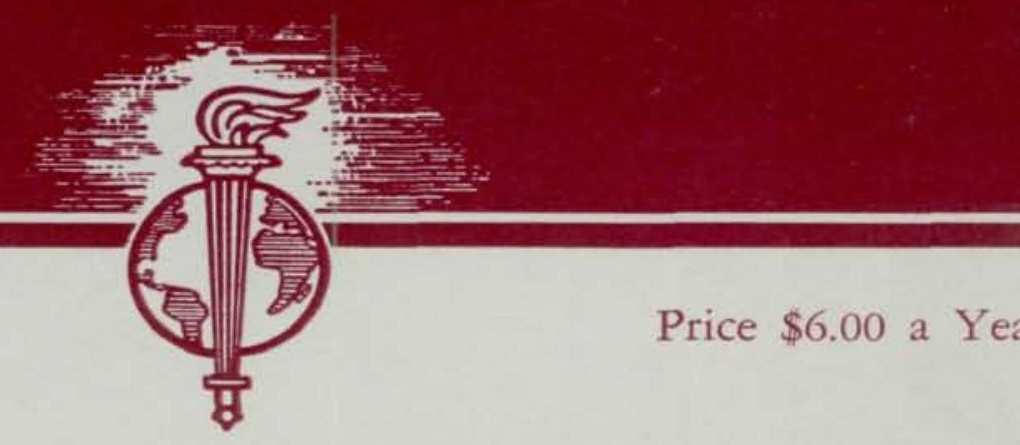

Autumn 1963 


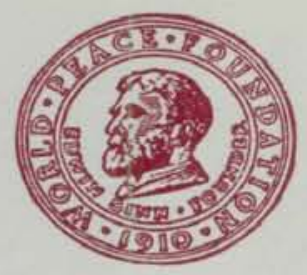

W O R L D P E A C E F O U N D A T I O N 40 Mt. Vernon Street, Boston, Massachusetts

Founded in 1910

Board of Trustees

Max F. Mrlitikan, President James Phinney Baxter, 3D Percy W. Bidwelt, Emeritus ROBERT R. BowIE Kingman Brewster, JR. Harvey H. Bundy Erwin D. Canham Leonard W. Cronkhtte Emeritus

George P. Gardner, Jr.

LeLAND M. Goodrich

Christian A. Herter

JosEpH E. JoHNSON

Milton Katz

Calvin H. Plimpton

Jerome Preston Secrefary-Treasurer

Paul C. Reardon

Arthur E. Whittemore

JEROME B. WIESNER*

Carroll. L. Wilson

*On leave of absence

\section{General Staff}

Alfred O. Hero, Jr.

$$
\text { Executive Secretary }
$$

Susan S. Bove

Louise DeCosta
7 HE World Peace Foundation is a 1 non-profit organization which was founded in rgro by Edwin Ginn, the educational publisher, for the purpose of promoting peace, justice, and good will among nations.

For many years the Foundation has sought to increase public understanding of international problems by an objective presentation of the facts of international relations.

Recently, increased attention has been focused on international organization through the publication of this journal and the maintenance of a library, specializing in documents and publications of governmental international organizations and secondary sources in the field. 


\title{
INTERNATIONAL ORGANIZATION
}

\author{
Volume XVII - No. 4
}

AUTUMN 1963

\section{BOARD OF EDITORS}

\author{
Norman J. Padelford, Chairman \\ Lincoln P. Bloomfield \\ Leo Gross \\ Roy Blough \\ H. Field Haviland, Jr. \\ Daniel S. Cheever \\ Stanley HoffmanN \\ Inis L. Claude, Jr. \\ WALTER R. SHARP \\ ANDrew Cordier \\ Kenneth W. Thompson \\ Rupert EMErson \\ Richard VaN Wagenen \\ Lawrence S. Finkelstein \\ Francis O. Wricox \\ Leland M. Goodrich \\ BRYCE WOOD

\begin{abstract}
Alfred O. Hero, Managing Editor
Susan S. Bove, Associate Editor

Louise DeCosta, Assistant Editor
\end{abstract}

Volume XVII, Number 4, Copyright 1963, World Peace Foundation 
International Organization is supported solely by the World Peace Foundation, a non-profit educational organization, and income from subscribers and advertisers. Statements of fact and opinion are made on the responsibility of the authors alone, and do not imply the endorsement of the Board of Editors or the Board of Trustees of the World Peace Foundation.

\section{Overseas Agents}

United Kingdom and the British Dominions except Canada: Stevens \& Sons Limited, in New Fetter Lane, London E.C.4. Subscription $£^{2-3}$ yearly; payment may be made in sterling.

Netherlands: N. V. Martinus Nijhoff, Lange Voorhout 9, The Hague.

Switzerland: La Librairie Payot, S.A., Lausanne.

International Organization. Published quarterly by the World Peace Foundation, Autumn 1963, Vol. XVII, No. 4. Editorial and Executive Offices, 40 Mt. Vernon Street, Boston 8, Mass. Entered as second-class matter February 18, 1947, at the post office at Boston, Mass., under the act of March 3, 1879. Subscriptions $\$ 6.00$ a year. Individual copies $\$ 2.00$. Postage prepaid to any address. 


\section{TABLE OF CONTENTS}

\section{Articles}

The Political Framework of the United Nations' Financial Problems.

Inis L. Claude, Ir. . . . . . . . . . . . . . . . . . . 83I

Norway and Collective Defense Organization. Richard J. Kerry . . 860

The Afro-Asian States and the Hungarian Question. Samir N. Anabtawi . . . . . . . . . . . . . . . . . . . . . . . . 872

Flections within the United Nations: An Experimental Study Utilizing

Statistical Analysis. Marshall R. Singer and Barton Sensenig III . . 901

\section{International Organizations: Summary of Activities}

I. United Natrons

General Assembly . . . . . . . . . . . . . . . . . 926

Security Council . . . . . . . . . . . . . . . . . . . . . 939

Economic and Social Council . . . . . . . . . . . . . . . 945

II. Specialized Agencies

International Bank for Reconstruction and Development . . . . . . . 969

International Monetary Fund . . . . . . . . . . . . . . . . . 976

United Nations Educational, Scientific and Cultural Organization . . . 978

World Health Organization . . . . . . . . . . . . . . . . . 979

III. Political and Regional Organizations

ANZUS Pacific Security Pact . . . . . . . . . . . . . . . . . 986

Caribbean Organization . . . . . . . . . . . . . . . . . 987

Council for Mutual Economic Assistance . . . . . . . . . . . . 988

Organization of African Unity . . . . . . . . . . . . . . . . . . . . 989

Organization of American States. . . . . . . . . . . . . . . . $99 \mathbf{r}$

Southeast Asia Treaty Organization . . . . . . . . . . . . . . . 993

IV. Other Functional Organizations

General Agreement on Tariffs and Trade . . . . . . . . . . . . . 994

Selected Bibliography . . . . . . . . . . . . . . . 997

Announcement of Grants for Research in International Organization 


\section{International Organization Prize Award}

To encourage creative writing by younger scholars in the broad field of United Nations and international organization affairs, the Board of Editors is pleased to announce the establishment of an International Organization Prize Award in the amount of $\$ 300$. This shall be for the best manuscript submitted on or before March 1, 1964, by an author not more than 32 years old on a theme of the author's choice in the field of international organization affairs.

Manuscripts may be on any aspect-political, economic, technical, or legal - of United Nations affairs, on the activities of other organizations including regional systems, or on theoretical aspects of international organization. In considering the manuscripts the judges will pay particular attention to

(a) their scholarly character,

(b) their original contribution to knowledge,

(c) their relevance to the field of international organization, and

(d) the gracefulness of their style and composition.

Manuscripts submitted for the International Organization Prize Award should not exceed 30 double-spaced, $81 \frac{1}{2}{ }^{\prime \prime} \times 11^{\prime \prime}$, typed pages, including footnotes. Manuscripts should be accompanied by a curriculum vitae of the author, including his date and place of birth. A manuscript submitted for the Award must be plainly marked as such and dated.

Manuscripts submitted for this Prize shall become the property of the Board of Editors. The Board reserves the right to make no award if, in its judgment, no manuscript submitted is worthy of receiving the Prize.

The prize-winning article will be published in International Organization. Other manuscripts judged of special merit may be awarded Honorable Mention and will be considered for publication in International Organization. Manuscripts accepted for publication will be accorded the customary reprint privileges.

Manuscripts will be judged by a committee of three members of the Board of Editors. Awards will be announced in the Summer 1964 issue of the magazine.

Norman J. PAdelford Chairman, Board of Editors 